\title{
ARTYKUŁY
}

Wojciech Kowalski

wojciech.kowalski@us.edu.pl

orcid.org/0000-0001-6532-9796

Politechnika Śląska

Wydział Organizacji i Zarządzania

ul. Roosevelta $26 / 28$

41-800 Zabrze

\section{Prawne aspekty rekonstrukcji dziedzictwa kulturowego}

Legal Aspects of Reconstruction of Cultural Heritage

Summary: After examining several different examples of reconstruction in the context of destroyed buildings and their ensembles, the author argues that the only acceptable form of analyzed activity is reconstruction sensu stricto, meaning in the narrow sense of this word, when it is based on proper documentation and aimed at restoring the building's original authenticity. All other examples, like $19^{\text {th }}$ century romantic castles or recent restorations of entire city centers, can only be classified as reconstructions sensu largo - in a very wide sense of the term. Then the change in legal approach to the concept of reconstruction is discussed. According to the Venice Charter, it was not accepted per se but slowly "legalized" with the passage of time, initially by placing the Warsaw Old Town on the World Heritage List in 1980 and then in documents like 2017 ICOMOS Guidance on post trauma recovery and reconstruction for world heritage cultural properties, where terms such as "modified reconstruction", "partial reconstruction" and others have been defined. The more recent and generally drafted 2018 Warsaw Recommendation on recovery and reconstruction of cultural heritage fully accepts the term "reconstruction." The paper ends with some remarks on the financial aspects of reconstruction.

Keywords: monuments, reconstruction, cultural heritage law 


\section{ARTYKUEY}

Wojciech Kowalski

Streszczenie: W artykule - po analizie różnych przykładów rekonstrukcji budowli i ich zespołów - autor przekonuje, że może być jedynie rekonstrukcja sensu stricto, tzn. w wąskim znaczeniu tego słowa, kiedy jest ona oparta na dobrej dokumentacji i dążeniu do zachowania lub przywrócenia autentyczności. Wszelkie inne przykłady, takie jak zamki romantyczne w XIX w. czy współczesne odbudowy dzielnic miast można nazywać jedynie rekonstrukcją sensu largo, czyli bardzo szeroko pojętą. W dalszej części przedstawiono zmianę podejścia do rekonstrukcji, która w Karcie Weneckiej była niedopuszczalna, ale z czasem doszło do swoistej jej „legalizacji”, np. poprzez umieszczenie na Liście Światowego Dziedzictwa odbudowanego Starego Miasta w Warszawie. Potem przyszły specjalne wytyczne ICOMOS dotyczące odbudowy i rekonstrukcji zabytków z 2017 r., w których zdefiniowano różne rodzaje rekonstrukcji, w tym m.in. „rekonstrukcję jak wcześniej”, „modyfikowaną rekonstrukcję”, "częściową rekonstrukcję" oraz „inne formy rekonstrukcji". Dokumentem mniej szczegółowym, ale za to dotyczącym szeroko pojętego dziedzictwa, jest przyjęta w 2018 r. tzw. Rekomendacja warszawska 0 odbudowie i rekonstrukcji dziedzictwa kulturowego. W artykule omówione zostały także kwestie finansowania rekonstrukcji.

Słowa kluczowe: zabytki, rekonstrukcja, prawo ochrony dziedzictwa kulturowego

Zagadnienie rekonstrukcji dotyka co najmniej dwóch zasadniczych kwestii prawnych. Po pierwsze, w dziedzinie ochrony zabytków jest pojęciem trudno prawnie definiowalnym ze względu na wielorakość skojarzeń i możliwych form, które mogą kryć się pod tą nazwą lub być za jej pomocą określane. Trzeba jednak je zdefiniować, a przynajmniej pokazać główne zjawiska mieszczące się w tej kategorii, gdyż prawo niewątpliwie znajdzie w odniesieniu do nich swoje zastosowanie. Druga kwestia to intuicyjne już w pierwszym momencie pytanie, czy rekonstrukcja jako, co do zasady, „odtworzenie” czegoś, co już było, jest w ogóle prawnie dopuszczalna, szczególnie w dziedzinie ochrony dziedzictwa kulturowego. Zarysowana problematyka jest zatem złożona i niniejszy artykuł jedynie ogólnie zarysuje jej główne aspekty prawne.

Próbę odpowiedzi na tak postawione pytania zacząć trzeba od analizy fenomenu rekonstrukcji. Już na wstępie należy podkreślić, że dotyczy on zarówno zabytków nieruchomych, jak i ruchomych i w odniesieniu do obydwu ich rodzajów budzi niejednokrotnie spore wątpliwości. Jakie zatem możemy wyróżnić przykłady z praktyki, mieszczące się chociażby bardzo ogólnie w pojęciu rekonstrukcji, które potem można by odpowiednio sklasyfikować i usystematyzować? 
Na początek nasuwają się najbardziej chyba znane rekonstrukcje, związane z tzw. likwidacją skutków wojny ${ }^{1}$. Wśród nich na pierwszym miejscu wyróżnić trzeba całkowitą lub daleko idącą odbudowę szczególnie ważnych dla dziedzictwa narodowego pojedynczych zabytków, a czasem i całych dzielnic miast. Oczywistą ilustracją pierwszego przypadku jest tu odbudowa zniszczonego w czasie II wojny światowej Zamku Królewskiego w Warszawie, którą planowano już kilka lat po jej zakończeniu, a podjętą dnia 2 lipca 1947 r. uchwałę sejmową w tej sprawie uzasadniono w sposób następujący:

Stąd płynie żywy, twórczy, przyszłościowy stosunek do przeszłości, stąd płynie ten symboliczny niejako wniosek - aby Warszawie i Narodowi przywrócić, dźwignąwszy go z ruin, założony w roku 1280 przez Konrada II Księcia Mazowieckiego, przebudowany z chwilą obioru przez Sejm Warszawy jako Stolicy Polski z końcem XVI wieku [...] - wysadzony w powietrze i przeorany czołgami hitlerowskimi w 1944 r. - Zamek Warszawski - żeby go [...] przywrócić jako świadectwo niespożytych sił narodu i majestatu Polski Ludowej².

Mimo podjęcia wówczas prac studialnych ${ }^{3}$, plan odbudowy zrealizowano dopiero w latach 1971-1988, odtwarzając nie tylko całą budowlę, ale także najważniejsze wnętrza historyczne, niektóre według zachowanych planów z XVII w. W strukturę wbudowano natomiast wszystkie licznie zachowane fragmenty na ich odpowiednie miejsce. Innym, bardziej współczesnym, ale podobnym przykładem, aczkolwiek w mniejszej skali, może być rekonstrukcja wnętrz Teatru Opery i Baletu w Tbilisi, zniszczonych w wyniku pożaru budynku w 1973 r. oraz wojny domowej w Gruzji w 1992 r., wykonana łącznie ze słynną kurtyną i kryształowym żyrandolem w dwóch etapach w latach 2003-20164.

Jako przykłady odbudowy zespołów zabytków podać można Warszawę i Gdańsk ${ }^{5}$. W przypadku Warszawy należy przy tym podkreślić, że rekonstrukcja odbyła się na podstawie specjalnej ustawy o odbudowie m. st. Warszawy, uchwa-

1 Por. szerzej na ten temat: W. Kowalski, Likwidacja skutków II wojny światowej w dziedzinie kultury, Instytut Kultury, Warszawa 1994.

2 Końcowy fragment przemówienia ówczesnego premiera Józefa Cyrankiewicza przed podjęciem uchwały, cyt. za: Sejm uchwalił odbudowę Zamku, „Ochrona Zabytków” 1949, nr 4, s. 217; o samej uchwale W. Kieszkowski, Materiały do rekonstrukcji Zamku Warszawskiego, „Ochrona Zabytków” 1949, nr 4, s. 250; J. Zachwatowicz, Zagadnienie odbudowy Zamku - jako rekonstrukcji jego formy i wnętrza, „Ochrona Zabytków” 1949, nr 4, s. 275.

3 Por. studia zamieszczone w „Ochronie Zabytków” 1949, nr 4: J. Dąbrowski, Problem rekonstrukcji części gotyckiej Zamku oraz przywrócenia zespołu wnętrz z czasów Władysława IV, s. 227 i n.; P. Biegański, Studia i prace wstępne do odbudowy Zamku Warszawskiego, s. 237 i n.; W. Kieszkowski, op. cit., s. 250 i n., J. Zachwatowicz, op. cit., s. 274 in.

4 N. lashvili, Tbilisi Opera and Ballet Theatre - Jewellery of the City. Cultural heritage, reconstruction, architecture, chandelier, curtain, w: A. Bender, M. Wrześniak, A. Wiśnicka (red.), Beautiful objects. Personal adornments and decorations for secular and sacred interiors, Wydawnictwo Naukowe Uniwersytetu Kardynała Stefana Wyszyńskiego, Warszawa 2017, s. 237 in.

5 Por. np. M. Gawlicki, Zabytkowa architektura Gdańska w latach 1945-1951. Kształtowanie koncepcji konserwacji i odbudowy, Wydawnictwo Słowo/Obraz Terytoria, Gdańsk 2012. 


\section{ARTYKUEY}

Wojciech Kowalski

lonej w 1947 r. ${ }^{6}$ Podjęte na jej podstawie prace miały rzeczywiście wielki rozmach. Według stanu z 2016 r., ponad połowę zabytków objętych rejestrem w tym mieście stanowiły zabytki odbudowane po II wojnie światowej. Na ogólną liczbę 924 pozycji rekonstrukcje to 497 obiektów? ${ }^{7}$, wśród których są nie tylko zespoły zabytkowe, względnie układy i zespoły zabudowy wraz z zielenią, lecz również założenia urbanistyczne z zespołami zabudowy ${ }^{8}$. Najbardziej rozpoznawalnym zespołem, prawie w całości odbudowanym w 1953 r., jest Stare Miasto, na terenie którego zachowano układ ulic i działek oraz przywrócono ogólny kształt budynków, ale bez rekonstruowania ich wnętrz. Nie odtwarzano też zasadniczo dekoracji zrekonstruowanych fasad, ale pokryto je malowidłami zaprojektowanymi na motywach przedwojennych przez współczesnych artystów. Na ogólnie podobnych zasadach odbudowano w latach 1945-1960 Stare Miasto w Gdańsku, które zniszczone zostało w głównej mierze w 1945 r.9

Innym typem odbudowy jest rekonstrukcja częściowa, zwykle obejmująca fragment budowli i wnętrz. Tak przywracano np. Zamek Królewski na Wawelu po odzyskaniu przez Polskę niepodległości w 1918 r., który był wcześniej przebudowany na koszary. Odbudowa polegała m.in. na wyburzeniu elementów dobudowanych, otwarciu zamurowanych wcześniej renesansowych arkad na dziedzińcu, odkryciu polichromii, przywróceniu kształtu oryginalnych pomieszczeń itp. W podobny sposób odtworzono Pałac Biskupi w Kielcach, najlepiej zachowaną rezydencję pałacową z I połowy XVII w. w Polsce. Po utracie pierwotnej funkcji był on od 1816 do $1971 \mathrm{r}$. używany na cele biurowe, usunięte zostały barokowe hełmy na wieżach, a pomieszczenia wewnętrzne przekształcone zostały zgodnie z nowym przeznaczeniem. Jednak już w latach 20. zrekonstruowano hełmy, a po przeznaczeniu pałacu na Muzeum Narodowe odtworzono dawne wnętrza, odkrywając przy tej okazji freski i zakryte sufitami bogato zdobione plafony ${ }^{10}$. W 2005 r. otwarty został dla publiczności także odtworzony w całości ogród włoski.

Ostatnią wreszcie formą rekonstrukcji, albo działaniem często za taką uważaną, jest tylko przywrócenie ogólnego kształtu dawnej zabudowy, zwykle bez odniesienia do poprzednio istniejących budowli czy choćby dokładnego rekonstruowania ich fragmentów. Czasem pisze się o potrzebie zapewnienia powrotu do dawnego „klimatu” lub charakteru danej dzielnicy. Następuje to poprzez budowę nowych obiektów w podobnej skali, kształcie i proporcjach, jak np. w Avignon

6 Ustawa z dnia 3 lipca 1947 r. o odbudowie m. st. Warszawy, Dz. U. Nr 52, poz. 268.

7 W. Kowalski, Prawno-autorska ochrona architektury XX wieku, „Ochrona Dziedzictwa Kulturowego” 2017, nr 3, s. 33.

8 Por. np. założenie urbanistyczne i zespół budowlany Akademii Obrony Narodowej w Rembertowie z lat 1900-1945, nr rej. A-1005, wpis z dnia 26 stycznia 2010 r.

9 Por. np. J. Friedrich, Odbudowa Głównego Miasta w Gdańsku w latach 1945-1960, Fundacja Terytoria Książki, Wydawnictwo Słowo/Obraz Terytoria, Gdańsk 2015.

10 Por. J.L. Adamczyk, T. Wróbel, Zabytki architektury na Kielecczyźnie, Kielce 2005, s. 16. 
i Elblągu, gdzie zachowano dawne podziały oraz formy parcelacyjne i komunikacyjne, a budynki nawiązują jedynie do dawnych form i tylko w niektórych miejscach są rekonstrukcjami ${ }^{11}$. Na podobnej zasadzie zbudowano zamek na ruinach dawnego zamku w Bobolicach, zburzonego przez Szwedów w XVII w. oraz Zamek Przemysła w Poznaniu ${ }^{12}$. W obydwu przypadkach nie zachowała się żadna dokumentacja, nie wiadomo nawet, jak te zamki wyglądały. Podobne kreacje powstawały już w XIX w. w duchu romantycznym, np. zamek w Pierrefonds i fortyfikacje w Carcassonne we Francji czy zamek Neuschwanstein w Bawarii.

Nieco inny cel towarzyszy rekonstrukcji ruchomości, które nie mają zwykle funkcji użytkowych, a ewentualna częściowa rekonstrukcja brakujących elementów dzieła sztuki służy jedynie ułatwieniu lub nawet umożliwieniu jego odbioru w kategoriach estetycznych. Dobry przykład takiej potrzeby podaje Bohdan Marconi, wyjaśniając, że gdybyśmy „zastosowali retusz neutralny [...] dla wykruszonej części oka w portrecie słynnego mistrza, patrząca na nas zezem postać portretowana zakłóciłaby odbiór dzieła"13.

Po pokazaniu możliwych przykładów funkcjonowania pojęcia „rekonstrukcja" przejść można do próby wyjaśnienia jej istoty, aby umożliwić stosowną ocenę w kategoriach prawnych. Już na wstępie należy podkreślić, że pojęcie to nie zostało zdefiniowane w aktach prawnych. Oprzeć się zatem trzeba na definicjach ogólnych. Otóż zgodnie z definicją encyklopedyczną, rekonstrukcja to „odtworzenie, odbudowa, uzupełnienie brakujących fragmentów budowli, rzeźby, malowidła; wykonana zgodnie z zasadami konserwacji zabytków"14. Podobne wyjaśnienie znajdujemy w słowniku oksfordzkim, gdzie słowo "reconstruction” tłumaczy się ogólnie jako „the action or process of reconstructing” (pol. „działanie lub proces rekonstrukcji”), ale ewentualne wątpliwości usuwa podany przykład: „It was theirs to decide [...] whether, from its ruins, fragments were to be collected for re-construction of the political edifice” (1791. Mackintosh. Vindic. Gall. Wks 1846 III. 30; pol. „Do nich należało, czy fragmenty miały być zebrane z ruin w celu rekonstrukcji politycznego gmachu”), a dalej jeszcze dodatkowe rozumienie: „C. The rebuilding of an area devastated by war"15 (pol. „Odbudowa rejonu zniszczonego przez wojnę"). Podane definicje warto uzupełnić przyjętą $w$ angielskiej doktrynie konserwatorskiej interpretacją czynności określanych jako „restoration”, które polegają na „all actions taken to modify the existing materials and structure of cultural property to rep-

11 Por. M. Lubocka-Hoffman, Retroversion - a conservation method of rebuilding of historic cities, w: W. Fałkowski, M. Konopka (red.), Common Heritage. Europe - Poland, Polish National Committee ICOMOS, Warsaw 2003, s. 49.

12 Por. I. Malawska, Zamki w Polsce - problem określenia zasobu, „Ochrona Zabytków” 2007, nr 4, s. 85.

13 B. Marconi, Estetyka i etyka w konserwacji. Malarstwo i rzeźba polichromowana, w: idem, O sztuce konserwacji, Wydawnictwo „Arkady”, Warszawa 1982, s. 29.

14 Rekonstrukcja [hasło], w: Encyklopedia PWN, t. 3, Warszawa 1999, s. 143.

15 Reconstruction [hasło], w: The Oxford English Dictionary, Clarendon Press, Oxford 1989, vol. XIII, s. 357. 


\section{ARTYKUtY}

Wojciech Kowalski

resent an earlier state” ${ }^{16}$ (pol. „całość działań podjętych w celu modyfikacji istniejących materiałów i konstrukcji dobra kultury, aby przedstawiało ono stan wcześniejszy”). Z tą interpretacją wyraźnie koresponduje wyjaśnienie pojęcia „konserwacja” w literaturze polskiej, według której polega ona na usuwaniu "naleciałości technicznie szkodliwych i zniekształcających oryginalny wyraz dzieła, na wzmocnieniu osłabionej struktury i opracowywaniu estetycznego wyrazu obiektu"17. Jak wynika jednoznacznie z przytoczonych definicji, pojęcie „rekonstrukcja” oznacza czynności zmierzające do przywrócenia danemu obiektowi stanu wcześniejszego, uważanego za oryginalny, czyli pierwotny. $W$ istocie chodzi więc o odtworzenie czegoś, co już w dawnej formie nie istnieje, ale powrót do tej formy jest możliwy w stopniu zdeterminowanym stosowaniem zasad konserwacji, tzn. przede wszystkim dzięki oparciu się na zachowanej lub odtworzonej dokumentacji. Analizując te kwestie, nie sposób nie zauważyć, że istota rekonstrukcji zblizzona jest do istoty pojęcia prawnego restytucji, które wywodzi się od łacińskiego restitutio in integrum, co oznacza także przywrócenie stanu poprzedniego, tyle że chodzi o stan rozumiany szerzej, a mianowicie całokształt stosunków, jakie istniały przed popełnieniem czynu negatywnie ocenianego przez prawo. Mogą one, rzecz jasna, obejmować także obowiązek odbudowy zniszczonej budowli' ${ }^{18}$.

Gdyby przyjrzeć się bliżej wspomnianym wyżej zjawiskom określanym jako rekonstrukcja, to trzeba zauważyć, że w ramach w miarę ścisłego rozumienia tego pojęcia mieszczą się przede wszystkim i wyłącznie przypadki odbudowy dążącej do możliwie wiernego odtworzenia nieistniejącego w całości lub w części obiektu zabytkowego. Niewątpliwie można tu mówić o całkowitej rekonstrukcji Zamku Królewskiego w Warszawie czy odbudowanych centrach miast, takich jak Stare Miasto w Warszawie i Gdańsku. W grę wchodzą także rekonstrukcje częściowe, jak przywrócenie dawnych wnętrz w Zamku Królewskim na Wawelu i w Pałacu Biskupim w Kielcach. We wszystkich tych przypadkach dążono bowiem do możliwie wiernego powrotu do dawnych form z wykorzystaniem oryginalnych fragmentów, niejednokrotnie zabezpieczanych jeszcze przed zburzeniem budowli, jak to miało miejsce w przypadku zamku warszawskiego, kiedy znane już były plany Niemców związane z jego zburzeniem. Przy odbudowie Starego Miasta wykorzystano natomiast wszystkie dawne fragmenty budowli znalezione w jego ruinach, a jak podkre-

16 Definicja pojęcia „restoration” według United Kingdom Institute of Conservation, Code of Ethics and Rules of Conduct, cyt. za: K. Walker-Tubb, Focusing Beyond the Microscope: Ethical Considerations in Conservation, „Art, Antiquity and Law” 1997, vol. II, z. 1, s. 42. Podobnie definiuje restaurację § 987(b) 5 kalifornijskiego kodeksu cywilnego. Pojęcie „restore” oznacza w nim: „to return, or cause to be returned, a deteriorated or damaged work of fine art as nearly as is feasible to its original state of condition, in accordance with prevailing standards".

17 Konserwacja [hasło], w: S. Kozakiewicz (red.), Słownik terminologiczny sztuk pięknych, PWN, Warszawa 1976, s. 232.

18 Por. szerzej na ten temat - W. Kowalski, Restitution of Works of Art pursuant to Private and Public International Law, Martinus Nijhoff, Boston-London 2002, s. 24 i n. Por. idem, Restytucja dzieł sztuki. Studium z dziedziny prawa międzynarodowego, Uniwersytet Śląski, Katowice 1993, s. 25 i n. 
ślono w decyzji o wpisie tego zespołu na Listę Światowego Dziedzictwa UNESCO, „polychrome decoration was executed using traditional techniques, including sgraffito" ${ }^{19}$ (pol. „dekoracja kolorowa wykonana została przy użyciu technik tradycyjnych, włączając w to sgrafitto"). Te same uwagi należy odnieść do wyjaśnionej wyżej idei rekonstrukcji stosowanej czasem przy konserwacji ruchomości, która dąży, co do zasady, do przywrócenia stanu poprzedniego w stopniu zapewniającym dobry odbiór estetyczny dzieła sztuki. Mając na uwadze wskazane okoliczności, wspomnianą praktykę odtwarzania należy określić rekonstrukcją sensu stricto, to znaczy rekonstrukcją w wąskim znaczeniu tego słowa, opartą na dobrej dokumentacji i dążeniu do zachowania lub przywrócenia autentyczności.

Wskazane wyżej dalsze przykłady, takie jak wznoszone w XIX w. zamki romantyczne czy zamki zbudowane na ruinach lub zaledwie w dawnej historycznej lokalizacji, jak w Bobolicach i Poznaniu, w sposób diametralny różnią się od opisanego i zilustrowanego wyżej rozumienia rekonstrukcji. Są bowiem pozbawione dokumentacyjnych podstaw źródłowych, a ich kształt wykreowany został jedynie przy wykorzystaniu głównych form typowych dla stylu odtwarzanej przez nie epoki. Jeżeli miałyby się one mimo to nazywać rekonstrukcjami, to można je nazwać jedynie rekonstrukcjami sensu largo, czyli bardzo szeroko pojętymi.

Po wyjaśnieniu omawianego pojęcia można przejść do analizy ewentualnych problemów prawnych. Chociaż wydawałoby się, że jest ono prawnie obojętne, to jednak istnieje co najmniej kilka kwestii wiążących się z rekonstrukcją, które zostały uregulowane. Jako pierwsze wyjaśnić trzeba stanowisko w tym zakresie prawa polskiego. Otóż obowiązujące prawo ochrony zabytków ${ }^{20}$ dopuszcza stosowanie rekonstrukcji jako jednej z form restauracji obiektu zabytkowego. Wynika to wprost $z$ art. 3 pkt 7 tego prawa, gdzie prace restauratorskie zdefiniowano jako „działania mające na celu wyeksponowanie wartości artystycznych i estetycznych zabytku, w tym, jeżeli istnieje taka potrzeba, uzupełnienie lub odtworzenie jego części, oraz dokumentowanie tych działań". Wskazane uzupełnienie lub odtworzenie części zabytku polega niewątpliwie na rekonstrukcji, której zastosowanie ustawodawca uzależnia od potrzeby wynikającej z realizacji celu restauracji, jakim jest wyeksponowanie wartości artystycznych i estetycznych obiektu. W świetle tej definicji nie można zatem zaliczyć do prac restauratorskich wspomnianych wyżej przykładów pełnej odbudowy zamku. Mając na uwadze dalsze przepisy omawianego prawa, nie oznacza to jednak całkowitego wykluczenia możliwości takiej praktyki, albowiem w określonej sytuacji przewidują one obowiązek „przywrócenia zabytku do poprzedniego stanu". W szczególności na podstawie art. 44 ust. 2 prawa

19 Historic Centre of Warsaw on World Heritage List, http://whc.unesco.org/en/list/30 [dostęp: 22.05.2019]. Szerzej na temat tych malowideł S. Jagiellak, Autentyzm dekoracji malarskich Starego Miasta w Warszawie, „Ochrona Dziedzictwa Kulturowego” 2017, nr 4, s. 93 i n.

20 Ustawa z dnia 23 lipca 2003 r. o ochronie zabytków i opiece nad zabytkami, tekst jedn. Dz. U. z 2017 r. poz. 2187 (dalej: prawo ochrony zabytków). 


\section{ARTYKUtY}

Wojciech Kowalski

ochrony zabytków wojewódzki konserwator zabytków wydaje taką decyzję, jeżeli przy zabytku wpisanym do rejestru zabytków prowadzone były roboty budowlane bez pozwolenia lub w sposób odbiegający od jego zakresu. Nakaz taki może być też wydany przez sąd prowadzący sprawę karną z art. 108 ust. tego prawa, który penalizuje niszczenie i uszkadzanie zabytków. Jak stanowi ustęp 4 tego przepisu, w razie skazania za uszkodzenie sąd orzeka obowiązek przywrócenia stanu poprzedniego, a jeśli obowiązek taki byłby niewykonalny - nawiązkę na rzecz Narodowego Funduszu Ochrony zabytków w wysokości nieprzekraczającej wartości uszkodzonego zabytku.

Orzecznictwo sądowe potwierdza, że nie są to przepisy martwe, a dobrym przykładem jest tu sprawa odbudowy zburzonej bez zezwolenia willi Julisin w Konstancinie koło Warszawy. Wprawdzie w jednym z orzeczeń w toku długiego procesu padło stwierdzenie, że nie jest możliwe nakazanie przywrócenia tego budynku do poprzedniego stanu, gdyż będzie to tylko kopia, ale ostatecznie Naczelny Sąd Administracyjny uznał w 2014 r. zaskarżoną decyzję wojewódzkiego konserwatora zabytków nakazującą odbudowę za zgodną z prawem. Zawiera ona szczegółowy opis willi i określa m.in. parametry dotyczące wielkości budynku, jego elewacji, dachu, okien, odtworzenia portyku itp. Częstsze są jednak przypadki nakazania relatywnie niewielkich odtworzeń. Typowym przykładem może tu być wyrok sądu akceptujący decyzję konserwatora nakazującą rekonstrukcję usuniętej stolarki okiennej ${ }^{21}$. W sprawie tej sąd ustalił, że

właściciele lokalu mieszkalnego w budynku, wpisanym do rejestru zabytków, dokonali wymiany stolarki okiennej stanowiącej przeszklenie loggi, na okno wykonane z PCV pozbawione profili. Ponadto zdemontowana została historyczna stolarka balkonowa, oddzielająca loggię od pokoju i w jej miejscu wstawione zostały współczesne drzwi rozsuwane.

Wspomniane prace wykonano bez wymaganego pozwolenia, a zdemontowana stolarka nie zachowała się. Sąd uznał więc, że „jedynym sposobem jest odtworzenie stolarki, wzorując się na istniejącej pierwotnej stolarce w pozostałych loggiach elewacji budynku, z zachowaniem formy, sposobu podziału, proporcji, profilowania oraz historycznego materiału". Dodatkowo zaś wyjaśnił, że

w przypadku obiektów zabytkowych, gdy zaistnieje konieczność wymiany okien, jedynym dopuszczalnym ze stanowiska konserwatorskiego rozwiązaniem jest odtworzenie cech charakterystycznych oryginalnej stolarki, czyli kształtu, proporcji, podziału i wielkości poszczególnych kwater i profili. Materiałem pozwalającym na odtworzenie cech charakterystycznych okna jest zaś drewno. Okna wykonane z PCV pozbawione profili nie spełniają tych szczególnych wymogów i odbiegają od oryginalnego wzoru.

${ }_{21}$ Wyrok Wojewódzkiego Sądu Administracyjnego w Warszawie z dnia 2 czerwca 2006 r., sygn. akt I SA/ Wa 1543/05, LEX nr 232927. 
Na marginesie tych uwag warto jeszcze zwrócić uwagę na dwa aspekty. Po pierwsze, obowiązek przywrócenia zabytku do poprzedniego stanu byłby zgodnie $z$ art. 44 ust. 4 prawa ochrony zabytków wykonany na swój koszt przez osobę naruszającą przepisy lub warunki pozwolenia. Po drugie, odbudowany obiekt nadal figurowałby w rejestrze zabytków, czym prawo polskie różni się od krajów zasadniczo niewpisujących do rejestru budowli rekonstruowanych. Przykładem stosowania tej zasady, acz nie bez ściśle określonych wyjątków, jest prawo amerykańskie. Wśród przyjętych bowiem w tym prawie "kryteriów wykluczających” (criteria for exclusion ${ }^{22}$ możliwość wpisu obiektu historycznego do National Register znajduje się przeniesienie go z pierwotnej lokalizacji oraz fakt, że jest on rekonstrukcją ${ }^{23}$. Wyjątkiem będzie sytuacja, gdy zrekonstruowana budowla została właściwie wykonana w odpowiednim otoczeniu i prezentuje w istotny sposób część planu rewaloryzacji, a nie zachował się jej odpowiednik ${ }^{24}$.

Po omówieniu prawa polskiego wypada odnieść się do regulacji prawnomiędzynarodowych. Już na wstępie można stwierdzić, że prawo to nie zajęło się dotąd zagadnieniem rekonstrukcji, np. nie znajdziemy na ten temat wzmianki w konwencji UNESCO dotyczącej ochrony światowego dziedzictwa kulturalnego i naturalnego z 1972 r. ${ }^{25}$ Pojawia się ona natomiast $w$ dokumentach doktrynalnych mających charakter tzw. soft law. Podstawowym dokumentem tego rodzaju jest tzw. Karta Wenecka z 1964 r., czyli Międzynarodowa Karta Konserwacji i Restauracji Zabytków i Miejsc Zabytkowych ${ }^{26}$, w której skodyfikowano podstawowe zasady ochrony i konserwacji dziedzictwa kulturowego. Stosunek karty do rekonstrukcji określony jest w definicji „restoration”, która jest jednym z głównych instrumentów takich działań. Otóż w art. 9 karty wyjaśniono, że celem owej restauracji jest zachowanie i ujawnienie wartości estetycznych i historycznych zabytku, przy czym opiera się ona na poszanowaniu oryginalnej substancji zabytkowej i autentycznych dokumentach. Restauracja kończy się w miejscu, w którym zaczynają się przypuszczenia, a jeżeli dalsze prace są konieczne, to powinny one odróżniać się od oryginalnej architektury i być oznaczone jako współczesne ${ }^{27}$. Zapis ten czytany wprost może

22 N. Tyler, T.J. Ligibel, I.R. Tyler, Historic Preservation, W. W. Norton \& Company, New York-London 2009, s. 148.

23 „[...] structures that have been moved from their original locations, reconstructed historic buildings" (ibidem, s. 148).

24 „A reconstructed building when accurately in suitable environment and presented in a dignified manner as part of a restoration master plan, and when no other building or structure with the same association has survived" (ibidem, s. 148).

25 Konwencja w sprawie ochrony światowego dziedzictwa kulturalnego i naturalnego, przyjęta w Paryżu dnia 16 listopada 1972 r. przez Konferencję Generalną Organizacji Narodów Zjednoczonych dla Wychowania, Nauki i Kultury na jej siedemnastej sesji, Dz. U. z 1976 r. Nr 32, poz. 190.

26 International charter for the conservation and restoration of monuments and sites. and restoration of monuments and sites, https://www.icomos.org/venicecharter2004 [dostęp: 17.05.2019].

27 Art. 9 Venice Charter: „Restore is to preserve and reveal the aesthetic and historic value of the monument and is based on respect for original material and authentic documents. It must stop at the point 


\section{ARTYKUtY}

Wojciech Kowalski

nie być rozumiany jednoznacznie, ale na oficjalnej stronie ICOMOS, który przyjął kartę jako swój podstawowy dokument w 1965 r., znajdujemy jego interpretację ujętą w postaci jednego $z$ pięciu głównych zasad karty ${ }^{28}$. Zdefiniowanej wyżej restauracji odpowiada zasada 3, zgodnie z którą należy

ją podejmować tylko w wypadkach niezbędnych, przy czym rekonstrukcja nie jest dopuszczona, a struktura i autentyczność materiałów ma być poszanowana. Jakikolwiek nowy element będzie dał się odróżnić, [...] a falsyfikacja w postaci zastąpienia brakujących fragmentów będzie wykluczona ${ }^{29}$.

Tak sformułowane podejście do rekonstrukcji od dawna było przedmiotem międzynarodowej debaty, a wiele głośnych przypadków celowego zniszczenia ważnych zabytków wymusiło niejako odstępstwo od tej doktryny w praktyce, jeżeli rozumieć ją dosłownie. Jako przykłady podaje się tutaj najczęściej powszechnie znane zniszczenie statuy Buddy w dolinie Bamyan w 2001 r. oraz zburzenie antycznego miasta Palmira, a także Alleppo ${ }^{30}$. Te przypadki dotyczą nowszych czasów, ale niewątpliwą zapowiedzią zmian była już decyzja o wpisie warszawskiego Starego Miasta na Listę Światowego Dziedzictwa w 1980 r. W decyzji o wpisie określono bowiem to miasto jako „wyjątkow[y] przykład prawie całkowitej rekonstrukcji historii w przedziale od XIII do XX wieku"31. Tak wyraźne i jednoznaczne podkreślenie wyjątkowości „prawie całkowitej” rekonstrukcji dowodzi o świadomym kroku dokonującego wpisu Komitetu Światowego Dziedzictwa w kierunku modyfikacji zasady ustanowionej w powołanej Karcie Weneckiej. Dodatkowo świadczy o tym uzasadnienie zastosowania w tym przypadku kryterium ewaluacyjnego (ii), w którym Komitet podkreślit, że: „Inicjatywa wyczerpujących i pełnych działań konserwatorskich w skali całego miasta historycznego była wyjątkowym doświadczeniem europejskim i wniosła wkład do weryfikacji doktryn i praktyk konserwatorskich"32. Dla pełni obrazu znaczenia tej decyzji można jeszcze przypomnieć uzasadnienie

where conjecture begins, and in this case moreover any extra work which is indispensable must be distinct from the architectural composition and must bear a contemporary stamp" (https://www.icomos.org/venicecharter2004 [dostęp: 17.05.2019]).

28 „[...] five major principles of the Charter” (https://www.icomos.org/venicecharter2004 [dostęp: 7.02.2019]).

29 „Restoration - will be undertaken only when necessary. No reconstruction should be admitted; the structure and authenticity of materials should be respected. Any new element should be distinguishable. [...]. Falsification in replacing missing parts is to be ruled out" (https://www.icomos.org/venicecharter2004 [dostęp: 7.02.2019]).

30 Ch. Cameron, Reconstruction: changing attitude, "The UNESCO Courier, many Voices, one World” JulySeptember 2017, s. 1.

31 „[...] an outstanding example of a near-total reconstruction of a span of history covering the $13^{\text {th }}$ to $20^{\text {th }}$ century" (Historic Centre of Warsaw on World Heritage List, op. cit.).

32 "The initiation of comprehensive conservation activities on the scale of entire historic city was a unique European experience and contributed to the verification of conservation doctrines and practices", uzasadnienie zastosowania kryterium (ii) (Historic Centre of Warsaw on World Heritage List, op. cit.). 
drugiego zastosowanego w decyzji kryterium. Było nim kryterium (vi), które zastosowano, stwierdzając, że:

Stare Miasto w Warszawie jest wyjątkowym przykładem pełnej rekonstrukcji miasta zniszczonego celowo i w całości. Fundamentem materialnej rekonstrukcji była wewnętrzna siła i determinacja narodu, która doprowadziła do rekonstrukcji dziedzictwa na skalę wyjątkową w historii świata ${ }^{33}$.

Dalszy proces umieszczania rekonstrukcji w ramach ochrony dziedzictwa, swoistej jej „legalizacji” w świetle wcześniejszych zasad, przyspieszony został przez poparcie przez UNESCO rekonstrukcji umieszczonych na Liście Światowego Dziedzictwa mauzoleów muzułmańskich w Timbuktu w Mali w 2015 r. po ich zniszczeniu trzy lata wcześniej. Przy tej okazji na wniosek Komitetu Światowego Dziedzictwa grupa ekspertów ICOMOS opracowała w 2017 r. specjalne wytyczne ${ }^{34}$ dotyczące odbudowy i rekonstrukcji zabytków znajdujących się na wspomnianej liście, w których zdefiniowano różne rodzaje rekonstrukcji, w tym m.in. „rekonstrukcję jak wcześniej”, „modyfikowaną rekonstrukcję”, „częściową rekonstrukcję” oraz „inne formy rekonstrukcji” ${ }^{35}$. Dokumentem mniej szczegółowym, ale za to dotyczącym szeroko pojętego dziedzictwa, nie tylko sklasyfikowanego jako światowe, jest przyjęta w 2018 r. tzw. Rekomendacja warszawska o odbudowie i rekonstrukcji dziedzictwa kulturowego ${ }^{36}$. Dopuszcza ona rekonstrukcję, co wynika z zawartego w niej jednoznacznego stwierdzenia, że proces odbudowy społeczeństwa po konflikcie lub katastrofie może obejmować także rekonstrukcję jako część odbudowy dziedzictwa ${ }^{37}$. Przy wyjaśnieniu pojęcia rekonstrukcji powołano się na wcześniejszy dokument dotyczący rekonstrukcji obiektów dziedzictwa światowego, w którym wyjaśniono, że oznacza ona „techniczny proces odtwarzania zasobów fizycznych i infrastruktury zniszczonych lub ciężko uszkodzonych w wyniku

33 „The Historic City of Warsaw is an exceptional example of comprehensive reconstruction of a city that had been deliberately and totally destroyed. The foundation of the material reconstruction was an inner strength and determination of the nation, which brought about the reconstruction of the heritage on an unique scale in the history of the world". Uzasadnienie zastosowania kryterium (vi) (Historic Centre of Warsaw on World Heritage List, op. cit.).

34 ICOMOS. Guidance on post trauma recovery and reconstruction for world heritage cultural properties, Paris 2017.

35 Reconstruction as before, modified reconstruction, partial reconstruction and other its forms, w: ICOMOS. Guidance on post trauma recovery and reconstruction for world heritage cultural properties, Paris 2017. Annexe 2.

36 Warsaw Recommendation on recovery and reconstruction of cultural heritage, http://www.mkidn.gov.pl/ media/docs/2018/20190118_rekomendacje_broszura__www_eng.pdf [dostęp: 7.02.2019].

37 "In post conflict and post disaster situations, the overall goal is the recovery of the society. [...] An essential part of this process is the recovery of the places' heritage, which may include reconstruction" (http://www.mkidn.gov.pl/media/docs/2018/20190118_rekomendacje_broszura__www_eng.pdf [dostęp: 7.02.2019]). 


\section{ARTYKUtY}

Wojciech Kowalski

konfliktu zbrojnego lub katastrofy"38. Prawidłowa realizacja rekonstrukcji wymaga zaś uwzględnienia wartości związanych z odtwarzanym dziedzictwem, które uzasadniały wpisanie go na Listę Światowego Dziedzictwa, uwarunkowań społecznych, dokumentacji, edukacji i dalszych warunków wymienionych w rekomendacji. Jak można sądzić, dokument ten zamyka obecną fazę omawianych zmian, dopuszczając rekonstrukcję w szerokim zakresie jako formę restytucji nie tylko uszkodzonych części zabytków, ale także całych obiektów oraz infrastruktury.

Ta konstatacja mogłaby zasadniczo zakończyć niniejszy artykuł, ale warto poruszyć jeszcze dwie dodatkowe kwestie łączące się z tematem. Chodzi mianowicie o charakter prawny rekonstrukcji z punktu widzenia projektanta prac rekonstrukcyjnych ${ }^{39}$ oraz sprawę kosztów takiego przedsięwzięcia.

Jeżeli chodzi o prawo polskie, kwestia pierwsza znajduje swoje wyjaśnienie w prawie autorskim, a szczególnie $\mathrm{w}$ art. 1 tego prawa ${ }^{40}$. Otóż bowiem wynika z niego, że przedmiotem ochrony jest "każdy przejaw działalności twórczej o indywidualnym charakterze, ustalonym w jakiejkolwiek postaci, niezależnie od wartości, przeznaczenia i sposobu wyrażenia". Dla prowadzonej analizy podstawowe znaczenie ma pierwszy warunek uznania danej działalności za utwór objęty ochroną prawną, którym musi być twórczy charakter tej działalności. Pamiętając istotę rekonstrukcji, polegającą na odtworzeniu czegoś, co już istniało, powstaje pytanie: czy takie odtworzenie może być uznane za twórcze? Jak się wydaje, udzielenie pozytywnej odpowiedzi na to pytanie będzie trudne, gdyż praca rekonstruktora wymaga niewątpliwie talentu i wiedzy, ale $z$ istoty swej nie może być uznana za twórczą, skoro jej przedmiotem jest odtworzenie dawnej postaci danego obiektu. Ocenę tę wzmacnia podkreślany w definicjach warunek wykonania rekonstrukcji według zasad konserwacji, tzn. na podstawie zachowanej lub odtworzonej dokumentacji. Ujmując tę sytuację w kategoriach prawa autorskiego, należy tu mówić o powtórnym utrwaleniu utworu, który powstał odpowiednio wcześniej, ale jego pierwotne utrwalenie uległo uszkodzeniu lub zniszczeniu. Wnioskiem tego rozumowania jest brak możliwości uznania pracy rekonstruktora za akt twórczy, a w konsekwencji niemożliwość prawnoautorskiej kwalifikacji tej pracy i jej wyniku jako utworu w rozumieniu tego prawa. Wynika z tego, że rekonstruktor nie będzie uznany za autora, ale nie oznacza to pozbawienia go wszelkich praw. Chronione będzie autorstwo jego pracy, aczkolwiek przez zastosowanie innych przepisów, a mianowicie chroniących dobra osobiste na podstawie prawa cywilnego ${ }^{41}$. Jednocześnie należy

38 „[...] a technical process for the restitution of destroyed or severely damaged physical assets and infrastructure following an armed conflict or a disaster" (http://www.mkidn.gov.pl/media/docs/2018/ 20190118_rekomendacje_broszura__www_eng.pdf [dostęp: 7.02.2019]).

39 Por. szczegółowe omówienie tej kwestii przez autora, W. Kowalski, Conservation of Works of Art under Polish Copyright Law, „Art, Antiquity and Law” 1999, vol. 4, z. 2, s. 126.

40 Ustawa z dnia 4 lutego 1994 r. o prawie autorskim i prawach pokrewnych, Dz. U. Nr 24, poz. 83, ze zm. (dalej: prawo autorskie).

41 Por. art. 23 ustawy z dnia 23 kwietnia 1964 r. Kodeks cywilny, Dz. U. Nr 16, poz. 93. 
wyjaśnić, że ustalenie to dotyczy wyłącznie wiernej rekonstrukcji danego zabytku. Każde bowiem odstępstwo od jego oryginalnej formy będzie można uznać za twórcze, gdyż jest ono wynikiem pracy twórczej rekonstruktora. Paradoksalnie można zatem powiedzieć, że rekonstrukcja nieudana, odchodząca od pierwowzoru, będzie utworem i będzie podlegać ochronie prawa autorskiego. W przypadku architektury nowszej będzie to jednocześnie opracowanie, czyli utwór zależny, z którego korzystanie wymagać będzie uzyskania zgody autora utworu rekonstruowanego. Podsumowując te uwagi, trzeba jednocześnie wyjaśnić, że opisane wyżej rekonstrukcje zabudowy staromiejskiej uzyskały pełną akceptację, w przypadku Starego Miasta w Warszawie nawet w postaci cytowanego wyżej wpisu na Listę Światowego Dziedzictwa, mimo że nie odtwarzały wiernie zburzonej zabudowy. Ze względu na nowe potrzeby czy funkcje nie mogły być przecież rekonstrukcjami wiernymi nawet w przypadkach, gdyby to było teoretycznie możliwe. Ich projekty w części uwzględniającej te zmiany z pewnością spełniają kryteria utworów i należy je traktować jako chronione prawem autorskim utwory architektoniczne.

Kwestia druga, czyli koszty rekonstrukcji - obciążają one zwykle podmiot zobowiązany do jej przeprowadzenia z tytułu odpowiedzialności np. za rozbiórkę lub uszkodzenie budowli. Jak to wyjaśniono wyżej, na podstawie polskiego prawa ochrony zabytków wojewódzki konserwator zabytków może nakazać w takiej sytuacji przywrócenie danego obiektu do poprzedniego stanu, a na zasadzie art. 44 ust. 4 prawa ochrony zabytków koszty tej rekonstrukcji ponosi osoba, która naruszyła przepisy tego prawa i doprowadziła do zniszczenia obiektu. Na generalnie podobnej zasadzie przedstawia się odpowiedzialność w przypadku szkód wojennych, które na podstawie prawa wojennego zobowiązane jest naprawić państwo uznane za agresora. Jak wyjaśnia jeden z klasyków współczesnej nauki prawa międzynarodowego publicznego, „w stosunkach międzynarodowych, jak i w innych stosunkach społecznych, naruszenie prawnych interesów jednego pomiotu prawa przez drugi podmiot tworzy odpowiedzialność prawną w różnych formach"42. Odpowiedzialność ta może obejmować także „przywrócenie stanu poprzedniego, restituio in integrum"43, a zatem również odtworzenie zniszczonych zabytków. Jednym z głównych zagadnień jest wówczas określenie wiążących się z tym kosztów. Interesującym przykładem dyskusji na ten temat i proponowanych sposobów ich obliczeń była kwestia pokrycia kosztów rekonstrukcji Zamku Królewskiego w Warszawie. Liczono się z nią jeszcze przed zakończeniem wojny, a próby wstępnego oszacowania odszkodowania za zburzenie zamku podjęto w kręgach Delega-

\footnotetext{
42 "In international relations, as in other social relations, the invasion of the legal interest of one subject of the law by another legal person creates responsibility in various forms" (I. Brownlie, System of the Law of Nations. State responsibility, Part I, Clarendon Press, Oxford University Press, New York 1983, s. 1). Zob. także W. Kowalski, Restitution..., s. 25 i n.

43 „[...] rétablissement de la situation antérieure, la restitutio in integrum” (P. Guggenheim, Les principes de droit international public, „Recueil des Cours” 1952, vol. 80, s. 133 i n.).
} 


\section{ARTYKUtY}

Wojciech Kowalski

tury Rządu RP na Kraj na Uchodźstwie ${ }^{44}$. Podstawowym zadaniem było ustalenie wartości materialnej obiektu, przy czym rozważano, czy należy ją określić dla momentu jego powstania, czy zburzenia. Za najwłaściwsze uznano wzięcie pod uwagę kosztów z czasów budowy Zamku, tym bardziej że zachowały się rachunki i można było te koszty precyzyjnie odtworzyć. Ponieważ jednak odnosiły się one głównie do XVIII W., „przeliczono” je jednocześnie na wartość zakupionych wówczas równolegle z budową obrazów, których ówczesna wartość też jest znana, a same obrazy zachowały się do dzisiaj i można ustalić także ich współczesną wartość rynkową. Uważano bowiem, że skoro odtworzenie autentycznego zabytku nie jest możliwe, to trzeba uzyskać równowartość kwoty wydatkowanej na jego stworzenie w formie innych zakupów, które król mógł dokonać za wydatki na Zamek, gdyby go nie budował. Jak należy rozumieć, z tej kwoty można by obiekt odbudować, a z ewentualnej reszty dokonać innych zakupów. Przypomnienie tego sposobu liczenia nie miało na celu argumentowania, że jest to jedyna metoda dokonania podobnych obliczeń. Chodziło jedynie o pokazanie, jak trudny i złożony jest to problem, który w przypadku świadomego i zamierzonego burzenia ważnych zabytków łączy współczesne koszty ewentualnej rekonstrukcji ze słusznym, jak się wydaje, odszkodowaniem.

\section{Bibliografia}

Adamczyk J.L., Wróbel T., Zabytki architektury na Kielecczyźnie, Kielce 2005.

Biegański P., Studia i prace wstępne do odbudowy Zamku Warszawskiego, „Ochrona Zabytków” $1949, \mathrm{nr} 4$.

Brownlie I., System of the Law of Nations. State responsibility, Part I, Clarendon Press, Oxford University Press, New York 1983.

Cameron Ch., Reconstruction: changing attitude, „The UNESCO Courier, many Voices, one World" July- September 2017.

Dąbrowski J., Problem rekonstrukcji części gotyckiej Zamku oraz przywrócenia zespołu wnętrz z czasów Władysława IV, „Ochrona Zabytków” 1949, nr 4.

Friedrich J., Odbudowa Głównego Miasta w Gdańsku w latach 1945-1960, Fundacja Terytoria Książki, Wydawnictwo Słowo/Obraz Terytoria, Gdańsk 2015.

Gawlicki M., Zabytkowa architektura Gdańska w latach 1945-1951. Kształtowanie koncepcji konserwacji i odbudowy, Wydawnictwo Słowo/Obraz Terytoria, Gdańsk 2012.

Guggenheim P., Les principes de droit international public, „Recueil des Cours” 1952, vol. 80.

Historic Centre of Warsaw on World Heritage List, http://whc.unesco.org/en/list/30 [dostęp: 22.05.2019].

http://www.mkidn.gov.pl/media/docs/2018/20190118_rekomendacje_broszura__www_ eng.pdf [dostęp: 7.02.2019].

44 Por. szerzej na ten temat łącznie z cytowanymi rachunkami z epoki i wyliczeniami - W. Kowalski, Likwidacja skutków..., s. 30-32. 
Iashvili N., Tbilisi Opera and Ballet Theatre - Jewellery of the City. Cultural heritage, reconstruction, architecture, chandelier, curtain, w: A. Bender, M. Wrześniak, A. Wiśnicka (red.), Beautiful objects. Personal adornments and decorations for secular and sacred interiors, Wydawnictwo Naukowe Uniwersytetu Kardynała Stefana Wyszyńskiego, Warszawa 2017.

ICOMOS. Guidance on post trauma recovery and reconstruction for world heritage cultural properties, Paris 2017.

International charter for the conservation and restoration of monuments and sites. and restoration of monuments and sites, https://www.icomos.org/venicecharter2004 [dostęp: 17.05.2019].

Jagiellak S., Autentyzm dekoracji malarskich Starego Miasta w Warszawie, „Ochrona Dziedzictwa Kulturowego" 2017, nr 4.

Kieszkowski W., Materiały do rekonstrukcji Zamku Warszawskiego, „Ochrona Zabytków” $1949, \mathrm{nr} 4$.

Konserwacja [hasło], w: S. Kozakiewicz (red.), Słownik terminologiczny sztuk pięknych, PWN, Warszawa 1976.

Konwencja w sprawie ochrony światowego dziedzictwa kulturalnego i naturalnego, przyjęta w Paryżu dnia 16 listopada 1972 r. przez Konferencję Generalną Organizacji Narodów Zjednoczonych dla Wychowania, Nauki i Kultury na jej siedemnastej sesji, Dz. U. z 1976 r. Nr 32, poz. 190.

Kowalski W., Conservation of Works of Art under Polish Copyright Law, „Art, Antiquity and Law” 1999, vol. 4, z. 2.

Kowalski W., Likwidacja skutków II wojny światowej w dziedzinie kultury, Instytut Kultury, Warszawa 1994.

Kowalski W., Prawno-autorska ochrona architektury XX wieku, „Ochrona Dziedzictwa Kulturowego" 2017, nr 3.

Kowalski W., Restitution of Works of Art pursuant to Private and Public International Law, Martinus Nijhoff, Boston-London 2002.

Kowalski W., Restytucja dzieł sztuki. Studium z dziedziny prawa międzynarodowego, Uniwersytet Śląski, Katowice 1993.

Lubocka-Hoffman M., Retroversion - a conservation method of rebuilding of historic cities, w: W. Fałkowski, M. Konopka (red.), Common Heritage. Europe - Poland, Polish National Committee ICOMOS, Warsaw 2003.

Malawska I., Zamki w Polsce - problem określenia zasobu, „Ochrona Zabytków” 2007, nr 4.

Marconi B., Estetyka i etyka w konserwacji. Malarstwo i rzeźba polichromowana, w: B. Marconi, O sztuce konserwacji, Wydawnictwo „Arkady”, Warszawa 1982.

Reconstruction [hasło], w: The Oxford English Dictionary, Clarendon Press, Oxford 1989, vol. XIII.

Reconstruction as before, modified reconstruction, partial reconstruction and other its forms, w: ICOMOS. Guidance on post trauma recovery and reconstruction for world heritage cultural properties, Paris 2017. Annexe 2.

Rekonstrukcja [hasło], w: Encyklopedia PWN, t. 3, Warszawa 1999.

Sejm uchwalił odbudowę Zamku, „Ochrona Zabytków” 1949, nr 4. 


\section{ARTYKUŁY}

Wojciech Kowalski

Tyler N., Ligibel T.J., I.R., Historic Preservation, W. W. Norton \& Company, New York-London 2009.

Ustawa z dnia 3 lipca 1947 r. o odbudowie m. st. Warszawy, Dz. U. Nr 52, poz. 268.

Ustawa z dnia 23 kwietnia 1964 r. Kodeks cywilny, Dz. U. Nr 16, poz. 93.

Ustawa z dnia 4 lutego 1994 r. o prawie autorskim i prawach pokrewnych, Dz. U. Nr 24, poz. 83, ze zm.

Ustawa z dnia 23 lipca 2003 r. o ochronie zabytków i opiece nad zabytkami, tekst jedn. Dz. U. z 2017 r. poz. 2187.

Walker-Tubb K., Focusing Beyond the Microscope: Ethical Considerations in Conservation, „Art, Antiquity and Law" 1997, vol. II, z. 1.

Warsaw Recommendation on recovery and reconstruction of cultural heritage, http://www. mkidn.gov.pl/media/docs/2018/20190118_rekomendacje_broszura__www_eng.pdf [dostęp: 7.02.2019].

Wyrok Wojewódzkiego Sądu Administracyjnego w Warszawie z dnia 2 czerwca 2006 r., sygn. akt I SA/Wa 1543/05, LEX nr 232927.

Zachwatowicz J., Zagadnienie odbudowy Zamku - jako rekonstrukcji jego formy i wnętrza, „Ochrona Zabytków” 1949, nr 4. 